\title{
Asylum Seekers Living in the Australian Community: A Casework and Reception Approach, Asylum Seeker Project, Hotham Mission, Melbourne
}

\author{
Grant Mitchell and Sara Kirsner
}

\begin{abstract}
In Australia, asylum seekers either are detained in immigration detention centres or, depending upon their mode of entry into Australia and the status of their application for protection, live in the community, often in a state of abject poverty. Hotham Mission's Asylum Seeker Project (ASP), a Melbourne-based non-governmental organization (NGO), is unique in Australia in its comprehensive work in housing and supporting asylum seekers in the community, particularly those released from detention. The work of the Asylum Seeker Project illustrates that it is possible, through the application of a comprehensive reception casework system, to adequately support asylum seekers in the community with their welfare needs and to prepare asylum seekers for all immigration outcomes. The Project thus provides a compassionate model of reception support and a viable alternative to immigration detention.

\section{Résumé}

En Australie, les demandeurs d'asile sont soit détenus dans des centres de détention de l'immigration, ou, dépendant leur mode d'arrivée en Australie et la situation de leur demande de protection, habitent dans la communauté - souvent dans des conditions de dénuement extrême. Le "Asylum Seeker Project " ('Projet des demandeurs $d u$ droit d'asile') du Hotham Mission, une organisation non gouvernementale (ONG) basée à Melbourne, est unique en son genre en Australie, du fait de ses services complets visant à loger et à soutenir les de-
\end{abstract}

mandeurs d'asile dans la communauté, tout spécialement ceux qui sont relâchés des centres de détention. Le travail accompli par le "Asylum Seekers Project» démontre qu'il est possible - en utilisant un système complet d'accueil individualisé - d'assister de façon effective les demandeurs d'asile vivant dans la communauté avec leurs besoins sociaux et de préparer les demandeurs d'asile à faire face à toutes les éventualités possibles à leurs demandes d'immigration. Ce faisant, le Projet fournit un modèle de ce qui peut être accompli en matière de soutien à l'accueil et une alternative viable à la détention.

\section{Australian Policy Regarding Asylum Seekers}

ustralia's policy response to asylum seekers and refu-
gees varies depending upon the way in which refu-
gees and asylum seekers enter or are chosen to enter the country. Australia maintains a focus on immigration control, reflected in specific categories and quotas determined for immigrants and refugees in addition to a focus on border protection. Australian policy ensures that there are different visa classes and consequently different welfare entitlements for refugees and humanitarian entrants who are selected for settlement by the government, for people who enter on a legal Australian visa and subsequently apply for asylum, and for those who enter Australian territory seeking asylum without legal documentation.

Approximately 12,000 refugees are accepted each year. Those who are selected "offshore" for settlement are generally eligible for full welfare, housing, and education entitlements. Under Australia's Migration Act (1992), those who arrive without a valid visa are immediately placed in 
detention, where they remain for the entire duration of their visa application. Due to delays in processing and the oftenlengthy process of appeal, many who seek asylum without valid Australian visas are detained for months or years on end. Also, if their application is rejected and the government is unable to remove them to their home country, the applicants generally remain in detention until removal can occur.

Those who arrive on a valid visa and later apply for asylum in Australia live in the community on limited, if any, income support. There currently do not exist any government funded community-based reception centres or housing for asylum seekers in Australia.

\section{Asylum Seekers in the Community}

There are approximately 8,000 asylum seekers living in the community on bridging visas. 1 In general, this group has never been in detention but arrived in Australia with valid visas, were immigration cleared, and lodged protection visa applications. This group of onshore asylum seekers makes up the majority of all asylum seekers in Australia and includes groups of people from East Timor and Sri Lanka.

The rights and entitlements for asylum seekers depend on which bridging visa they hold and the particular stage of their case. Since July 1997, all asylum seekers who have not applied for a Protection Visa within forty-five days of arrival in Australia are refused the right to work and receive medical assistance. If asylum seekers lodged their application within forty-five days and have not appealed a negative decision on the application, beyond the initial stage of appeal to the Refugee Review Tribunal, they are entitled to work and receive subsidized medical assistance.

If asylum seekers have not received a first decision on their visa or a visa rejection within six months from the Refugee Review Tribunal, they may receive a federally funded Asylum Seeker Assistance Scheme payment through the Australian Red Cross. However, many asylum seekers have no right to work, Medicare, or any welfare payment. This includes all asylum seekers awaiting a humanitarian decision from the Immigration Minister and all asylum seekers released from detention on a Bridging Visa $\mathrm{E}$, including those released on psychological or medical grounds.

\section{The Asylum Seeker Project: A Community-Based Response}

Hotham Mission's Asylum Seeker Project (ASP) is a Melbourne-based non-governmental organization, working with asylum seekers who have no right to work, no welfare payments or any form of income, and no entitlement to health assistance. The Asylum Seeker Project began with the support of the Australian Uniting Church in early 1997. The project moved formally to Hotham Mission in 2000. The project has for more than six years provided housing and support to homeless asylum seekers, and now works with over 200 asylum seekers in thirty-four properties across Melbourne.

The ASP provides free housing, casework, and volunteer support, pays for emergencies, and provides monthly cash relief. Most clients have no family or other supports in Australia and some have been released from detention into the project's care for psychological or medical reasons. Almost all clients are on a Bridging Visa E, which denies access to government support or mainstream services. Neither the asylum seekers nor the ASP receive financial assistance from the government.

On 10 December 2002, the Asylum Seeker Project was awarded Australia's National Human Rights Award for the Community by the Human Rights and Equal Opportunity Commission. The project was praised by the judges for the way in which it has not only directly assisted needy asylum seekers by providing support to them when they have nowhere else to go, but also by demonstrating to the government that it is possible to systematically house asylum seekers released from detention. In September 2003, the Asylum Seeker Project was nominated for the French Republic's Human Rights Prize for its work with detainees.

The project has recently undertaken research into the welfare needs and immigration outcomes of asylum seekers living in the community in order to provide qualitative and quantitative evidence of the issues and also to contribute to dialogue on new approaches for case managing asylum seekers, both in detention and in the community.

\section{Client Group}

The ASP works with asylum seekers who live in the community on Bridging Visa E. There are two groups of asylum seekers living on this visa: asylum seekers who applied for refuge while living in the community, and asylum seekers who have been released from detention on a discretionary basis (generally due to special humanitarian needs, being a minor who can be provided with adequate community care, or because they have an Australian spouse).

\section{Bridging Visa E}

A bridging visa gives applicants the legal right to stay in Australia while they are being considered for another visa. Applicants are eligible for a bridging visa if there has been:

- an application for a visa that can be granted in Australia,

- an application for a visa has not yet been formally determined,

- an application lodged in a court about their visa, or

- an appeal made to the Minister for Immigration regarding the grant of a visa. 


\section{Population Characteristics}

The ASP's research ${ }^{2}$ revealed that while the majority of clients are single men, much of the client group also consists of families or single parents with young children, an issue of particular concern given their lack of income and ability to access medical assistance. The table below portrays the characteristics of the client group with whom the ASP worked between February 2001and February 2003. This includes information regarding gender, age, family status (in Australia), country of origin, means of arrival, visa status, and time spent in Australia. A total of 111 cases (including families, couples, and singles) are represented, totalling 203 asylum seekers. Of these, 37 cases have had a final immigration outcome, while the project is still working with 74 cases.

\begin{tabular}{|c|c|c|}
\hline Gender & Total & $\%$ of Total \\
\hline Male & 124 & 61.1 \\
\hline Female & 79 & 38.9 \\
\hline Total & 203 & 100.0 \\
\hline Age & Total & $\%$ of Total \\
\hline $0-15$ & 44 & 21.7 \\
\hline $16-25$ & 39 & 19.2 \\
\hline $25-65$ & 119 & 58.6 \\
\hline $65+$ & 1 & 0.5 \\
\hline Total & 203 & 100.0 \\
\hline Family Status & Total & $\%$ of Total \\
\hline Single & 60 & 54.05 \\
\hline Two-parent families & 20 & 18.02 \\
\hline Single-mother family & 16 & 14.41 \\
\hline Single-father family & 1 & 0.90 \\
\hline Couples & 10 & 9.01 \\
\hline Unaccompanied child & 3 & 2.70 \\
\hline Siblings & 1 & 0.90 \\
\hline Total & 111 & 100.0 \\
\hline
\end{tabular}

\begin{tabular}{|c|c|c|}
\hline Means of Arrival & Total & $\%$ of Total \\
\hline Plane & 100 & 90.09 \\
\hline Boat & 8 & 7.21 \\
\hline Boat-stowaway & 2 & 1.80 \\
\hline Working on ship & 1 & 0.90 \\
\hline Total & 111 & 100.0 \\
\hline Plane Arrivals With Visa & Total & \%of Total \\
\hline Tourist & 43 & 42.57 \\
\hline Visitor & 22 & 21.78 \\
\hline Student & 21 & 20.79 \\
\hline Business & 5 & 4.95 \\
\hline Other & 10 & 9.90 \\
\hline Total & 101 & 100.0 \\
\hline $\begin{array}{l}\text { Boat Arrivals } \\
\text { Country of origin/ethnicity }\end{array}$ & Total & $\%$ of Total \\
\hline Afghanistan & 4 & 36.36 \\
\hline Iran & 2 & 18.18 \\
\hline Kenya (stowaway) & 2 & 18.18 \\
\hline Palestinian Territories & 1 & 9.09 \\
\hline Iraq & 1 & 9.09 \\
\hline Srilanka (work'g on ship) & 1 & 9.09 \\
\hline Total & 11 & 100.00 \\
\hline $\begin{array}{l}\text { Boat Arrivals } \\
\text { Country of Origin (first 20) }\end{array}$ & Total & $\%$ of Total \\
\hline Srilanka & 30 & 27.03 \\
\hline Russia & 8 & 7.21 \\
\hline Iran & 6 & 5.41 \\
\hline Albania & 5 & 4.50 \\
\hline India & 5 & 4.50 \\
\hline Pakistan & 5 & 4.50 \\
\hline Afghanistan & 4 & 3.60 \\
\hline
\end{tabular}




\begin{tabular}{|c|c|c|}
\hline Egypt & 4 & 3,60 \\
\hline Ethiopia & 4 & 3.60 \\
\hline Turkey & 4 & 3,60 \\
\hline China & 3 & 2.70 \\
\hline Palestinian Territories & 3 & 2.70 \\
\hline Serbia/Croatia & 3 & 2.70 \\
\hline Iraq & 2 & 1.80 \\
\hline Eritrea & 2 & 1.80 \\
\hline Ethiopia & 2 & 1.80 \\
\hline Angola & 2 & 1.80 \\
\hline Kenya & 2 & 1.80 \\
\hline Somalia & 2 & 1.80 \\
\hline Other & 15 & 13.51 \\
\hline Total & 111 & 100.0 \\
\hline Time Spent in Detention & Total & $\%$ of Total \\
\hline Never & 76 & 68.47 \\
\hline Less than three months & 12 & 10.81 \\
\hline $3-6$ months & 5 & 4.50 \\
\hline $6-12$ months & 7 & 6.31 \\
\hline More than 12 months & 11 & 9.91 \\
\hline Total & 111 & 100.0 \\
\hline $\begin{array}{l}\text { Total no. who have been } \\
\text { in detention }\end{array}$ & 35 & 31.53 \\
\hline Time Spent in Australia & Total & $\%$ of Total \\
\hline Under 12 months & 4 & 3.60 \\
\hline $1-3$ years & 44 & 39.64 \\
\hline $4-5$ years & 29 & 26.13 \\
\hline 6 years plus & 32 & 28.83 \\
\hline Not answered/do not know & 2 & 1.80 \\
\hline Total & 111 & 100.0 \\
\hline
\end{tabular}

The ASP's research indicated that the majority of asylum seekers live in abject poverty and are forced to rely on minimal handouts from agencies and charities. Ninety-five per cent of asylum seekers had no work rights or access to medical services and 23 per cent had never had an income while in Australia. Such a situation means that families and individuals are forced into dependency, relying on family members, religious organizations, and community groups in order to meet their basic needs. Furthermore, 44 per cent of asylum seekers were in debt to friends or lawyers, or had outstanding bills or detention center costs (asylum seekers can be billed for time spent in detention). Twenty-four per cent claimed to have been refused medical treatment due to their lack of status, funds, or eligibility for medical assistance. Financial destitution has led asylum seekers to experience ongoing risk of homelessness, whereby at least 68 per cent were homeless or at risk of homelessness.

The impact of the above factors on those who were single mothers, vulnerable families, children at risk, and/or experiencing serious medical, mental health, and torture and trauma related issues was of particular concern to the Asylum Seeker Project. The ASP's research ${ }^{3}$ indicated that asylum seekers released from detention were three times more likely to seek medical attention, particularly from mental health services, than those asylum seekers who have never been in detention. Two other issues observed for a number of detention releasees were a comparative high use of medical services and a high dependence on medication. While the research was inconclusive as to the reasons for higher medical use of services by detention releasees, much research has documented the way in which detention has had a negative impact on psychosocial health. ${ }^{4}$ This may, therefore, also account for the levels of casework and support for detention releasees required from the ASP, which was more than three times higher for detention releasees than community-based asylum seekers.

\section{Case Managing Asylum Seekers in the Community}

The ASP has taken a reception/welfare-based approach in its work with asylum seekers. This approach is in place in order to ensure the utmost duty of care to asylum seekers, to support, prepare, and empower asylum seekers and facilitate the best possible immigration outcomes, whether they be settlement or return outcomes. Much of ASP's work with asylum seekers is about providing a supportive and safe "holding space" while they await a final decision. For workers and volunteers, providing that "holding space" may mean many things: providing housing, advice, legal assistance, social work, counselling, assisting practically, or being a support person. Ultimately it is about building trust and 
being consistent in the work and relationship with the asylum seeker, who is often highly anxious over both past traumatic experiences and the uncertainty of their future. The core principle to ASP's work with asylum seekers is in respecting and valuing each person as an individual with dignity, with specific skills and needs.

The ASP therefore models its work on a reception response rather than a settlement response. Early intervention is the ideal approach, as it is preventative rather than reactive, particularly in terms of negotiating possible crisis issues. In the case of ASP, this work is provided in two ways: firstly, via initial assessment and case coordination, and secondly, via ongoing housing support and casework. This includes empowering and preparing clients for all immigration outcomes.

Providing consistent casework, preferably with an ongoing worker, has been found to be crucial when working with asylum seekers, particularly in addressing a client's lack of trust in authority, agencies, and strangers. Furthermore, ensuring that the asylum seekers completely understand the situation in which they have found themselves (determination process, welfare situation, etc.) assists them in coping with the situation and in making the few decisions they are able to make.

Other important issues dealt with include cultural sensitivity, trauma or medical issues, and asylum seekers' orientation to their new surroundings. The Project aims to support through empowering and resourcing clients, and by proving a supportive role that is both realistic and sustainable, but also compassionate and consistent, for the period of time that the asylum seeker is awaiting a final outcome.

Staff and volunteers are encouraged to be mindful of professional boundaries and possible vicarious traumatization and to make very clear their role to clients. As in any social, community, or welfare work context, professional boundaries are crucial. This, however, is particularly so in working with asylum seekers who may face an uncertain immigration outcome. In Australia, there is a focus on assisting refugees to resettle where workers' tasks are often focused on assisting a person to access resources, develop networks, and integrate into the community. However, the ASP's reception work pertains only to the duration of the determination process. As not all asylum seekers will be granted residency, workers need both to be prepared for all possible outcomes and, ideally, to have a mechanism to raise concerns that have come to their attention, such as mental health issues or new information about a case.

As case termination is a constant for workers, it is important to:
- set in place the appropriate means of communicating with those who are departing, farewells, etc.;

- allow time for discussion and working through closure, particularly in dealing with abrupt terminations, when asylum seekers must leave quickly; and

- allow adequate time for hand-over if a different authority or worker is to become involved.

\section{Outcomes of the Case Management Model}

\section{Housing}

The ASP has been successful in developing networks and relationships with a variety of housing providers and churches. By fully utilizing available housing stock, particularly church properties, ASP has been extremely successful in reducing the level of homelessness for asylum seekers despite receiving no government funding or governmentfunded properties. The project has extensive asylum-seeker housing experience, currently accommodating over 100 asylum seekers with no income, in thirty-eight properties throughout Melbourne.

Recent feedback from asylum seekers in ASP housing indicated a high level of satisfaction with both the appropriateness of housing and the level of support. The role of volunteers who make home visits has played a particularly important role in providing both ongoing support and a preventative response to vulnerable asylum seekers, particularly those experiencing depression, anxiety, or difficulties in coping with their predicament.

There are concerns, however, as to the sustainability of such a housing program, given increasing demands, heavy reliance on donated or subsidized properties and volunteers, and a general lack of funds, particularly from government sources.

\section{Case Examples}

Many asylum-seeker families spent time living in unacceptable conditions prior to presenting to the project. A family from South Asia, who had awaited a decision since 1997, had lived for many years with very little income. The family of four lived in a back shed in a friend's home with no running water in cramped and unsanitary conditions. When the family lost their right to work, the family was told they had to leave. Faced with homelessness, and not aware of their option to contact the Red Cross previously, the family later found them and were referred to ASP who is currently housing the family in a church property. 
A number of single females have presented as very vulnerable and susceptible to abuse, having to depend on people they don't know very well or who don't always have their interests at heart. A young woman from the Horn of Africa who lodged her protection visa application in 2000 spent most of her time with no income and chronically homeless, moving between friends until the welcome was outstayed, then moving on. Her days were spent trying to access food banks and looking for housing. She said she was often treated like a servant and felt scared much of the time. She faced high levels of anxiety, depression, and health issues. At one point she was hospitalized for malnutrition before the project was contacted and found housing for her.

Many more single young males have presented to the ASP after having spent time living on lounge room floors, in cars, in a mosque, and a number on the street.

\section{Income}

The ASP assists asylum seekers through a Basic Living Assistance Program, providing monthly cash relief. The ASP initiated the Basic Living Assistance (BLA) Program in 2000, and it is the only ongoing non-governmental funded financial assistance program specifically for ineligible asylum seekers available in Melbourne. Though crucial for the support of this group, at a maximum of $\$ 35$ per week, it rarely covers even basic items. The allowance does, however, allow asylum seekers to buy basic food items and limited transport and communication. This is particularly vital for single mothers and unwell asylum seekers, unable to access larger welfare agencies and food banks. Also provided is assistance for housing, medical and living emergencies, and assistance with referrals to health, education, recreation, and legal services. The project's total emergency relief and housing budget is currently $\$ 30,000$ per month, assisting over 200 asylum seekers. Besides some funding and donation from a charitable trust, there are no regular funds coming into the Basic Living Assistance Program. All remaining funds come from community groups or individual donations.

\section{Health}

Asylum seekers reported experiencing high levels of anxiety and depression. Loss of work rights and income exacerbated such issues and contributed to increased isolation. In response, the ASP introduced support programs such as "LinkUp," linking volunteers to asylum seekers and to the men's, mothers', and youth groups. There is, however, a general lack of funding and thus of counseling and mental health

\section{Case examples}

The ASP works with a number of single mothers who have no form of income. One mother from South Asia arrived in 2001 with her three children. Having no income in the first few months, she used her remaining funds before being cleared for payments from the Australian Red Cross. Since receiving a refusal of her first negative decision from the Refugee Review Tribunal more than one year ago, she lost her entitlement to receive the Red Cross funds. With no income, she could not afford to pay for food or rent, forcing her and her three children into homelessness and severe poverty. ASP has assisted since that time with Basic Living Assistance and housing, though the family has had to move three times to different crisis and church properties.

A number of single male asylum seekers have never had an income while in Australia. A male asylum seeker from the Middle East approached a migration agent within two weeks of arrival in Australia; however, the agent failed to lodge his application for protection within forty-five days, leaving the man without work rights or medical assistance for four years. As he was ineligible for Australian Red Cross payments, he faced constant homelessness and presented in very poor health and nutrition.

services for ineligible asylum seekers. Long waiting lists and inflexible service criteria further affected asylum seekers' ability to access the few services for which they were eligible.

The seriousness of health issues for community-based asylum seekers and the difficulties of accessing services, documented as early as $1996,{ }^{5}$ have prompted the emergence of a number of initiatives in Melbourne. The ASP, together with Refugee and Asylum Seeker Health Network (RASHN), Bula Bula Asylum Seeker Health Centre, Asylum Seeker Specialist Clinic, and the Red Cross, have been successful in reducing the number of refused services due to individual advocacy and referral to free services. A network of free services, including hospital services, specialists, and general practitioners, has emerged and the hard work of the above groups should be commended. Undoubtedly there would have been a larger percentage of refused services if not for these initiatives, and indeed anecdotal evidence from other states around Australia indicates a less coordinated approach to community-based asylum-seeker health and far fewer services available. 


\section{Case example}

One mother from the Middle East living in the Project's care had been on more than ten different prescriptions for various health ailments, including sleeping tablets and anti-depressants, during her time in detention. Not being provided with sufficient medical records for this period, she stopped a number of these medications quickly after release, which had some adverse effects on her health, such as dizziness and heart palpitations. She was generally unaware of exactly what medications she had taken in detention, their purpose, or the correct dosage. In response, the mother sought out medical attention very frequently, as was the case during her time in detention.

\section{Immigration Outcomes}

Refugee and humanitarian issues are generally viewed, not in immigration terms, but in a context of international obligations under various conventions and covenants. However, for the research referred to in this paper, the final decisions pertaining to protection visa holders, i.e. refusal of visa and return to country of origin or third country, approval of Temporary or Permanent Protection Visa, were defined as an immigration outcome.

\begin{tabular}{|l|c|c|}
\hline Outcomes & \multicolumn{1}{c|}{ Total } & \% of Total \\
\hline Detained & 1 & 2.70 \\
\hline Detained and Returned & 2 & 5.40 \\
\hline Voluntarily left Australia & 18 & 48.64 \\
\hline TPV/THV & 14 & 37.83 \\
\hline PV & 2 & 5.40 \\
\hline Absconded & 0 & 0.00 \\
\hline Total & 37 & 100.0 \\
\hline \hline
\end{tabular}

\begin{tabular}{|c|c|}
\hline $\begin{array}{l}\text { Voluntary Departur } \\
\text { Country of Origin) }\end{array}$ & Total \\
\hline Iran & 3 \\
\hline Srilanka & 3 \\
\hline Cyprus & 2 \\
\hline India & 2 \\
\hline
\end{tabular}

\begin{tabular}{|l|c|}
\hline Serbia & 2 \\
\hline Albania & 1 \\
\hline Congo & 1 \\
\hline Ethiopia & 1 \\
\hline Iraq & 1 \\
\hline Pakistan & 1 \\
\hline Russia & 1 \\
\hline Total & 18 \\
\hline
\end{tabular}

Asylum seekers usually have only two possible outcomes, settlement or return. In Australia, asylum seekers who have been successfully granted refugee status may also receive a Temporary Protection Visa after which a refugee needs to reapply for protection. Of all final outcomes recorded by ASP in the last two years, 43 per cent of all asylum seekers were approved, receiving either a Temporary Protection Visa or a Permanent Visa, and 57 per cent were rejected and left the country. No asylum seeker absconded. Of the 21 cases finally refused, 18 cases ( 85 per cent) involved voluntary departure, divided between voluntary repatriation (57 per cent) and departure for a third country (29 per cent).

The high level of repatriation at 85 per cent is particularly evident given that 95 per cent of asylum seekers interviewed had no form of income and thus few possibilities to make their own travel arrangements. Exploration of third-country options was facilitated by the fact that almost 50 per cent of all surveyed asylum seekers were in possession of a valid passport, and was made possible through the provision of funds from the Project and other agencies and churches. It is, however, unsustainable for small community agencies to fund travel costs on anything more than an emergency basis.

Further improvements on the level of returns would no doubt occur if there were increased resources to better work with clients at the final stages and if the Australian Immigration Department allocated funds for reintegration and travel (including third countries) and allowed more flexibility in notice given to leave the country.

The lack of income does affect people's choices to depart Australia. Two asylum seekers released from detention on a Bridging Visa E wanted to return home voluntarily but did not have work rights to pay for the travel or the issuance of a new passport. As the Project cannot fund travel for all clients, the government advised them that they would have to return to detention where the fares could be paid. As they did not wish to return to detention and feared prolonged detention pending removal, they appealed further. The 
Immigration Department has recently indicated it will further explore these travel and return issues facing community-based asylum seekers. Alternatively, allowing work rights or income support at the final stages would enable asylum seekers to better plan and prepare for either return or settlement.

\section{Final Stages of Asylum-Seekers Return: ASP Response}

The high figures for voluntary repatriation highlight the success of ASP's casework system in preparing, supporting, and empowering asylum seekers in the final stages. Working with asylum seekers at the final stages is a challenge, particularly when addressing clients' concerns about having to leave Australia, being rejected or returned. In many cases the issue of return is only raised with an asylum seeker once a final decision is imminent or has been made.

Assisting clients to think about, prepare, and ready themselves for all possible immigration outcomes as soon as possible is vital. However, discussing the possibility of having to leave Australia is a challenge due to high anxiety levels and the amount invested in the determination process.

There are three major options for refused asylum seekers: third-country options, voluntary repatriation, or forced return. Voluntary repatriation indicates a degree of confidence in the determination process and ideally involves a mechanism to monitor a percentage of returns to ensure safety, dignity, and security. It is important that asylum seekers are satisfied that they have been properly represented and that any new information has been fully considered prior to a final decision. It is equally important that caseworkers are able to provide the Immigration Department with information affecting a client's capacity to leave the country, such as medical, mental health, family, or humanitarian issues.

The ASP has found that bringing up the subject of a final decision on return needs to be approached with sensitivity to the client's unique situation and only if sufficient trust has been gained and the asylum seeker is ready. It is important that the exploration of return issues is raised in a way that does not diminish the level of trust the client may have developed with the worker and that does not deny their refugee claims. Instead, it should be explored as putting their interests first and looking at all their options. Furthermore, it is important that a clear distinction is made between the government Department of Immigration's responsibility in implementing immigration decisions and the caseworker's role in providing support and preparation during the process. The ASP has concluded that any discussion with the client should not instill false hope.

A number of approaches have been taken by caseworkers in preparing asylum seekers for return:
- ensuring asylum seekers are properly legally represented, are able to contribute to putting their case together, and understand decisions made in their case;

- discussing all potential outcomes as early as possible;

- providing updated, independent country information;

- providing statistics on the percentage of refugee approvals for the country of origin;

- briefing the client on changes in the country, politically, socially, etc.;

- exploring third-country options where applicable; ${ }^{6}$

- exploring the possibility of domestic relocation with the client;

- empowering asylum seekers to undertake their own research, particularly using the internet or library;

- being realistic and open about the information provided or discovered;

- empowering asylum seekers to make as many preparations as they can; calling family members, arranging on-arrival accommodation and people to meet them;

- for asylum seekers with particular needs, making referrals, care plans, or organizing on-arrival support;

- ideally, providing statistics and case studies of the outcomes of returned cases; and

- ideally, ensuring reintegration funds are available.

\section{Absconding and the Availability for Return}

A key concern for government, and a consistent argument in favour of detention, is ensuring the availability of asylum seekers for removal. This concern raises a number of issues:

- the actual risk of absconding;

- the role of caseworkers and the Government Immigration Department; and

- the ability to track asylum seekers in the community. Although there is always some possibility of absconding, the experience of ASP and indeed international findings is that the actual risk is minimal. This may in part be due to the strong incentive for asylum seekers to comply during the determination process and should be considered in the context that authorities are aware of a final negative outcome prior to the asylum seeker, and are thus able to make an individual risk assessment at that point. ${ }^{7}$

Given, however, that there may be some risk of absconding, this can be minimized by:

- compliance requirements in the community, such as regular reporting;

- living assistance linked to maintained contact with authorities;

- risk assessments; and

- comprehensive case management.

An important distinction needs to be made at this point between the responsibility of the government to implement 
immigration decisions and the role of caseworkers and NGOs in supporting and preparing asylum seekers throughout the process. The Department of Immigration's compliance section is ultimately responsible for ensuring asylum seekers comply with expulsion orders, which for community based asylum seekers in most cases involves twenty-eight days notice to make travel arrangements or risk being detained and removed.

The role of the caseworker is crucial, as it is at this point that they can provide the Immigration Department with any new information that may affect a person's ability to travel or safety upon return. At the point of imminent return the caseworker's role at the ASP has therefore involved:

- encouraging asylum seekers to comply with decisions;

- maintaining regular contact with the client;

- ensuring the client's contact details are accurate, and

- ensuring clients have the means to report to the Department of Immigration (travel, telephone cards, etc.)

The Department of Immigration, however, is ultimately responsible for ensuring the availability of asylum seekers for return, while caseworkers have a legal obligation to inform the department if a client has absconded or there is an apparent risk that they will.

It is, however, the experience of ASP that in the majority of cases forced removal or detention is neither desirable nor necessary. With caseworker support, asylum seekers are prepared, supported, and empowered throughout the process and are more likely to comply with decisions and more able to either cope with return or settle successfully. Such outcomes provide evidence for how a community-based reception response can provide a viable alternative to immigration detention.

\section{Conclusions}

Asylum seekers in Australia on Bridging Visa E were found to live in a state of extreme poverty. Lack of income, work rights, and access to health services increased people's experiences of homelessness, debts, and experiences of isolation and anxiety, resulting in a particularly negative impact on families, especially single mothers and those who were unwell and experiencing major torture and trauma related issues.

The reception/welfare casework response administered by the Hotham Mission's Asylum Seeker Project was successful in significantly increasing access to legal, medical, and other services. Furthermore, the housing options and support provided by ASP were found to greatly reduce the level of homelessness and degree of poverty, isolation, and destitution faced by many asylum seekers. Under ASP's comprehensive program, casework, housing, living assistance, and support programs complemented each other and provided a high standard of care for asylum seekers, a remarkable achievement in view of the lack of resources and funds for this group.

Further outcomes of welfare-based case management systems include: assisting decision makers to make informed decisions as to whether a person is required to remain in detention or whether they are able to be released into the community, and what needs or risks are present; tracking asylum seekers through the stages of detention and into the community; ensuring continuity of care and ongoing social and welfare support; and improving outcomes on return and settlement, as well as reducing crises or incidents. Such outcomes illustrate that a reception-based model is a viable and compassionate alternative to detention and does not involve the same psychosocial risk factors as does long-term immigration detention. Of overwhelming concern is that this work is unsustainable without government funds to ensure supports and resources are in place for this vulnerable group.

To further reduce the vulnerability and difficulties experienced by asylum seekers living in the community on Bridging Visa E, the ASP recommends that asylum-seeker children have access to a welfare payment from lodging to final outcome and including asylum seekers released from detention on bridging visas, that asylum seekers have access to health coverage from lodging of application to final outcome and including asylum seekers released from detention on bridging visas, and that at least one family member has access to work rights, including asylum seekers released from detention on bridging visas. Furthermore, the ASP proposes that the rule requiring people to seek asylum within forty-five days be abandoned and that financial assistance be provided for those seeking to return but with no funds available to assist with airfares or on-arrival support.

\section{Notes}

1. Amnesty International Australia, "Refugees," Asylum Seekers Fact Sheet 14, <http://www.amnesty.org.au/refugees/ref-fact 14.html $>$ (accessed 12 October 2003).

2. Asylum Seeker Project, Welfare Issues and Immigration Outcomes for Asylum Seekers on Bridging Visa E (Melbourne, Australia: Asylum Seeker Project, Hotham Mission, 2003). For a full copy of this report, or for a more detailed discussion regarding the ASP's casework/reception model, please contact Grant Mitchell at the Asylum Seeker Project, Hotham Mission, or by e-mail at asp@sub.net.au; or see <http://www.hothammission.org.au>.

3. Ibid.

4. D. Silove, Z. Steel, and C. Watters, "Policies of Deterrence and the Mental Health of Asylum Seekers," Journal of the American Medical Association 284 (2000): 604-11; M. Smith, "Desper- 
ately Seeking Asylum: The Plight of Asylum Seekers in Australia," New Doctor 74 (Summer 2000-1): 21-22; A. Sultan and K. O'Sullivan, "Psychological Disturbances in Asylum Seekers Held in Long Term Detention: A Participant-Observer Account," Medical Journal of Australia 175 (2001): 593-96; and B. Drozdek, A. Noor, M. Lutt, and D. Foy, "Chronic PTSD and Medical Services Utilisation by Asylum Seekers," Journal of Refugee Studies 16, no. 2 (2003): 211.

5. I. Sinnerbrook, D. Silove, V. Manicavasagar, Z. Steel, and A. Field, "Asylum Seekers: General Health Status and Problems with Access to Health Care," Medical Journal of Australia 165 (1996): 634-37.

6. Refugee Council of Australia, Position Paper, RCOA Position Paper on Australia's Reintegration Package for Afghan Refugees (April 2003), <http://www.refugeecouncil.org.au/position04 2003.htm > (accessed 5 August 2003).

7. E. Sullivan, F. Mottino, A. Khashu, and M. O’Neil “Testing community supervision for the INS: An evaluation of the Appearance Assistance Program", VERA Institute of Justice, Volume 1 (August 2000), <http://www.vera.org/section4/section4_4.asp > (accessed 31 October 2002).

Grant Mitchell [B.A., M.A. (Social Anthropology)] is the Coordinator of the Asylum Seeker Project, Hotham Missions, a Melbourne-based NGO which provides housing, casework, financial assistance, and referral to asylum seekers in the community with no work rights.

Sara Kirsner [B.A., B.S.W. (Hons.)] is a social worker and youth refugee development worker at the Ecumenical Migration Centre of the Brotherhood Laurence, Melbourne. 